\title{
EXPRESSION OF TYPE IV PROCOLLAGEN AND PROLYL 4-HYDROX- YLASE MRNA IN CARBON TETRACHLORIDE-INDUCED LIVER FIBROSIS STUDIED BY IN SITU HYBRIDIZATION
}

\author{
Takeo AIDA, Hiroyuki YAMADA and Goro ASANO \\ Department of Pathology, Nippon Medical School, 1-1-5 Sendagi, \\ Bunkyo-ku, Tokyo 113
}

Received for publication September 12, 1989 and in revised form July 27, 1990

\begin{abstract}
An experimental model of liver fibrosis was used to study the expression of type IV procollagen and prolyl 4-hydroxylase mRNAs by in situ hybridization. Paraffin sections of rat liver tissue were examined using non-radioactive digoxigenin-labeled cDNA probes and in situ hybridization employing mouse $\alpha 1$ (IV) procollagen cDNA and chicken prolyl 4-hydroxylase $\beta$-subunit cDNA in order to identify cells responsible for the production of type IV procollagen and prolyl 4hydroxylase mRNAs after administration of carbon tetrachloride $\left(\mathbf{C C l}_{4}\right)$. Localization of type IV procollagen and prolyl 4-hydroxylase mRNAs was demonstrated in the cytoplasm of mesenchymal cells after six weeks of $\mathbf{C C l}_{\mathbf{4}}$ administration. Type IV procollagen and prolyl 4-hydroxylase mRNAs were noted in hepatocytes after eight and ten weeks respectively. The expression of type IV procollagen mRNA was found in a large number of hepatocytes in proportion to the extent of fibrosis. These results suggest that in addition to the mesenchymal cells, hepatocytes also play an important role in fibrogenesis of the liver.
\end{abstract}

Prolyl 4-hydroxylase is a key enzyme in collagen biosynthesis, in which it catalyzes the conversion of peptidyl proline to peptidyl hydroxyproline in collagenous polypeptides (11). It has been reported that an increase in collagen synthesis is usually accompanied by an increase in prolyl 4-hydroxylase (1) and this has also been found to be the case in liver fibrosis (18).

Collagen type IV is a nonfibrillar collagen (23), the amount of which in the liver contributes to the rearrangement of the lobular architecture, in turn possibly modulating hepatocellular function and being involved in portal hypertension (13). Some reports have suggested that this collagen in liver is synthesized mainly by fibroblasts or the precursor cells $(4,14)$. On the other hand, it has been reported that hepatocytes are able to produce several types of collagen and other extracellular matrix components in vitro $(6,20,24)$.

Molecular biological studies using slot-blot hybridization have revealed that procollagen mRNAs are present in fibrotic lesions in liver tissue. However, since the individual cells containing procollagen mRNA cannot be recognized by the filter hybridization technique (16), it is unclear which types of cell contribute to the production of collagen in liver fibrosis. Using the in situ hybridization technique, the cells

Mailing address: Takeo Aida, Department of Pathology, Nippon Medical School, 1-1-5 Sendagi, Bunkyo-ku, Tokyo 113, Japan. 
that contribute to the synthesis of collagen could be identified. In this study, the hepatic localization of type IV procollagen mRNA and prolyl 4-hydroxylase mRNA was examined by in situ hybridization at various stages after administration of carbon tetrachloride $\left(\mathrm{CCl}_{4}\right)$ to rats.

\section{MATERIALS AND METHODS}

Fifty percent $\mathrm{CCl}_{4}$ in olive oil $(2 \mathrm{ml} / \mathrm{kg}$ body weight) was given to male Wistar rats (initial weight, 100-120 g) by intraperitoneal injection twice a week for 10 weeks. Five rats were killed in each group after 1, 2, 4, 6, 8 and 10 weeks of treatment. The control rats were treated with normal saline.

For histological observation, the liver specimens were fixed in $10 \%$ formalin, embedded in paraffin, sectioned and stained with $\mathrm{H} \& \mathrm{E}$ and Azan stains.

For in situ hybridization, mouse $\alpha 1$ (IV) procollagen C87 clone cDNA (1.3 k bp, $7 \mathrm{~S}$ region) in plasmid pBR 322 was generously provided by Dr. Linda Wood (26), and chicken prolyl 4-hydroxylase $\beta$-subunit $9-10 \mathrm{~B}$ cDNA (700 bp, $\mathrm{N}$-terminal region) in plasmid Puc 9 (10) and the Pst-EcoR1 fragment of pBR 322 (750 bp) were used as controls (Fig. 1). The cDNA probes were labeled with digoxigenin-dUTP by the random priming method using a DNA labeling and detection kit (Boehringer Mannheim $\mathrm{GmbH}$ ). Most of the digoxigenin-labeled cDNA probes were detected in the 250-400 bp nucleotide region by ethidium bromide staining in 1\% agar gel.

The modified Hayashi method was used for the preparation of paraffin sections of liver tissue (7). The sections were rehydrated with Dulbecco's phosphate-buffered saline (PBS) and incubated with proteinase K $(10 \mu \mathrm{g} / \mathrm{ml}$ Sigma Chemical Co.) in Dulbecco's PBS for $10 \mathrm{~min}$ at $37^{\circ} \mathrm{C}$. Then, the sections were post-fixed in $4 \%$ paraformaldehyde/PBS for $5 \mathrm{~min}$, and quenched twice with glycine $(2 \mathrm{mg} / \mathrm{ml})$ in Dulbecco's PBS. The sections were kept in $40 \%(\mathrm{v} / \mathrm{v})$ deionized formamide/2x SSC. The hybridization buffer contained $0.6 \mathrm{M} \mathrm{NaCl}, 1 \mathrm{mM}$ EDTA, $10 \mathrm{mM}$ Tris$\mathrm{HCl}$ (pH 7.6), $120 \mu \mathrm{g} / \mathrm{ml}$ herring sperm DNA (Boehringer Mannheim GmbH), $200 \mu$ $\mathrm{g} / \mathrm{ml}$ yeast RNA (Boehringer Mannheim $\mathrm{GmbH}$ ), 1x Denhart's solution, 10\% (v/v) dextran sulfate (Sigma Chemical Co.), $40 \%$ deionized formamide and 300-500 ng/ml labeled DNA probe (denatured). Fifty microliters of the hybridization buffer were applied to each section, and the sections were incubated in a moist chamber for 14-16 hr at $40^{\circ} \mathrm{C}$, then washed three times with $50 \%$ formamide/2x SSC for one $\mathrm{hr}$ at room temperature (RT) and washed twice with $2 x$ SSC for $15 \mathrm{~min}$. For immunological detection, the same kit for DNA labeling was used. The sections were washed briefly with buffer $1(100 \mathrm{mM}$ Tris- $\mathrm{HCl}, 150 \mathrm{mM} \mathrm{NaCl}, \mathrm{pH} \mathrm{7.6)}$ solution, and incubated with $0.5 \%(\mathrm{w} / \mathrm{v})$ blocking reagent in buffer 1 solution for $30 \mathrm{~min}$ at RT. After washing again briefly with buffer 1 solution, the sections were incubated with a 1/5000 dilution of polyclonal sheep anti-digoxigenin $\mathrm{Fab}$ fragment conjugated with alkaline phosphatase in buffer 1 solution for $30 \mathrm{~min}$ at RT. The sections were washed twice with buffer 1 solution for $15 \mathrm{~min}$ at $\mathrm{RT}$ and equilibrated with the buffer $2(100 \mathrm{mM}$ Tris-HCl, $100 \mathrm{mM} \mathrm{NaCl}, 50 \mathrm{mM} \mathrm{MgCl}_{2}, \mathrm{pH}$ 9.5) solution for $10 \mathrm{~min}$ at $\mathrm{RT}$. Then, the sections were incubated with coloring solution including NBT and BCIP in a dark box for $30 \mathrm{~min}$ and the reaction was stopped with TE buffer $(10 \mathrm{mM}$ Tris-HCl, $1 \mathrm{mM}$ EDTA, pH 8.0). The sections were mounted with aqueous mounting medium (Daido Sangyo Co.) and observed by light microscopy. 


\section{RESULTS}

Morphological findings:

After four weeks of $\mathrm{CCl}_{4}$ administration, lipid droplets were demonstrated in the hepatic intracellular regions of the central zones and in the parenchymal areas. After six weeks of $\mathrm{CCl}_{4}$ administration, acidophilic and necrotic hepatocytes were observed along the septal area and cell regeneration had become prominent. Nodules of regenerating hepatocytes were completely surrounded by fibrous septa including proliferating bile ducts, arterioles and venules, followed by cirrhotic change.

Localization of type IV procollagen and prolyl 4-hydroxylase mRNAs:

Control and experimental liver sections showed no hybridization with the labeled Pst-EcoRI fragment of the plasmid PBR 322 probe (data not shown). Type IV procollagen mRNA and prolyl 4-hydroxylase mRNA were not detected until four weeks after administration of $\mathrm{CCl}_{4}$. However, both mRNA were observed in the mesenchymal cells in the portal area and the surrounding zone of central veins at six weeks (Fig. 2). After eight weeks, type IV procollagen mRNA was observed not only in the mesenchymal cells but also in some hepatocytes located close to central veins and in the fibrous septa (Fig. 3). Type IV procollagen mRNA was observed much more clearly in the mesenchymal cells after ten weeks than at eight weeks. Prolyl 4-hydroxylase mRNA was also observed in the mesenchymal cells in the fibrous septa and hepatocytes (Fig. 4).
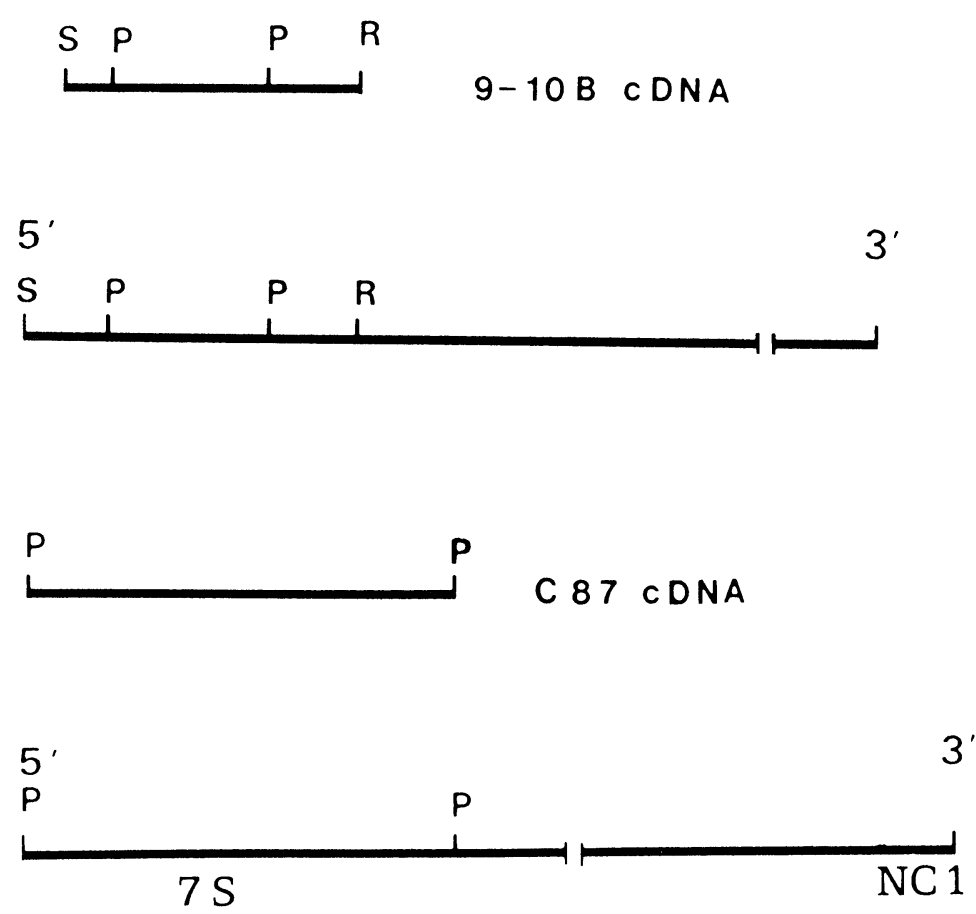

FIG. 1. Structures of prolyl 4-hydroxylase (9-10 B) and type IV procollagen (C 87) cDNAs used for in situ hybridization. 


\section{DISCUSSION}

Collagen fibers are a major structural component for the maintenance of architectural integrity in the liver (21). The toxic effect of $\mathrm{CCl}_{4}$ is due to its conversion of $\mathrm{CCl}_{4}$ to the highly reactive toxic free radical $\mathrm{CCl}_{3}\left(\mathrm{CCl}_{4}+\mathrm{e} \rightarrow \mathrm{CCl}_{3}+\mathrm{Cl}^{-}\right)$in the smooth endoplasmic reticulum of the liver cells (8). Free radicals may cause peroxidation of lipids in cellular and organellar membranes (9). A single dose of $\mathrm{CCl}_{4}$ leads to centrizonal necrosis and steatosis. The subsequent fibrosis is probably a complex inflammaotry reaction that includes immune and repair responses (17).

After liver injury, the endothelia, hepatocytes and mesenchymal cells contribute to the production of extracellular matrix and neovascularization in Disse's spaces (22). Hepatocytes as well as mesenchymal cells may contribute to collagen metabolism. Mature hepatocytes are capable of simultaneously synthesizing various types of collagen including types I, III and IV in vitro (3). Immunohistochemically, type I and IV collagens are detected in the fibrous septa in cirrhotic liver $(2,12)$. In situ hybridization can effectively demonstrate mRNAs in liver cells. In this study, type IV procollagen mRNA was found to be localized in the cytoplasm of mesenchymal cells and hepatocytes by in situ hybridization. An increase in $\alpha 1$ (I), $\alpha 1$ (III) and $\alpha 1$ (IV) procollagen mRNA levels has already been found in $\mathrm{CCl}_{4}$ induced hepatic fibrosis $(15,16)$. Increased amounts of mRNAs for type IV collagen and prolyl 4hydorxylase may be found at an early stage in the development of hepatic fibrosis (18). The increase in tissue collagen is correlated with an increase of procollagen and prolyl 4-hydroxylase activities in mouse teratocarcinoma cell lines F9 and P19 (19). However, the amounts of types I, III and IV procollagens do not increase simultaneously $(15,18)$.

The genes for the type IV procollagen $\alpha 1$ (IV) and $\alpha 2$ (IV) chains have been found on chromosome 13, being located on opposite strands and sharing a 120-bp promotor region (5). In mouse F9 cells, an increase has been found in the type IV procollagen gene, which is transcriptionally regulated by retinoic acid and dibutyril cyclic AMP (25). The regulation of type IV procollagen at the transcriptional level may be different from that of other types of collagen in fibrotic liver. From the results of our present study, it is concluded that hepatocytes as well as mesenchymal cells are responsible for the production of collagen after hepatocellular injury.

\section{ACKNOWLEDGMENTS}

We would like to thank Dr. L. Wood and Dr. W. Kao for providing the $\alpha 1$ (IV) procollagen cDNA clone and $\mathrm{PH}$ cDNA clone.

Figs. 2a, b. Type IV procollagen (a) and prolyl 4-hydroxylase mRNAs (b) are detected in the mesenchymal cells of portal area and surrounding central veins in the paraffin section of rat liver tissue after six weeks of $\mathrm{CCl}_{4}$ administration. $\times 100$

Figs. 3a-c. Type IV procollagen mRNA is detected in the hepatocytes $(\mathrm{H})$ and endothelial cells $(\mathrm{E})$ close to a central vein (a) and in fibrous septa (b, c) after eight weeks. $\times 100$

FIGs. 4a-c. After ten weeks, a large number of mesenchymal cells are noted in the fibrous periportal zone (a, H \& E). Type IV procollagen mRNA is cleary detected in the hepatocytes $(\mathrm{H})$, endothelial cells (E) and mesenchymal cells of periportal zone (b). Prolyl 4-hydroxylase mRNA is detected in the mesenchymal cells and hepatocytes of periportal zone (c). $\quad \times 100$ 

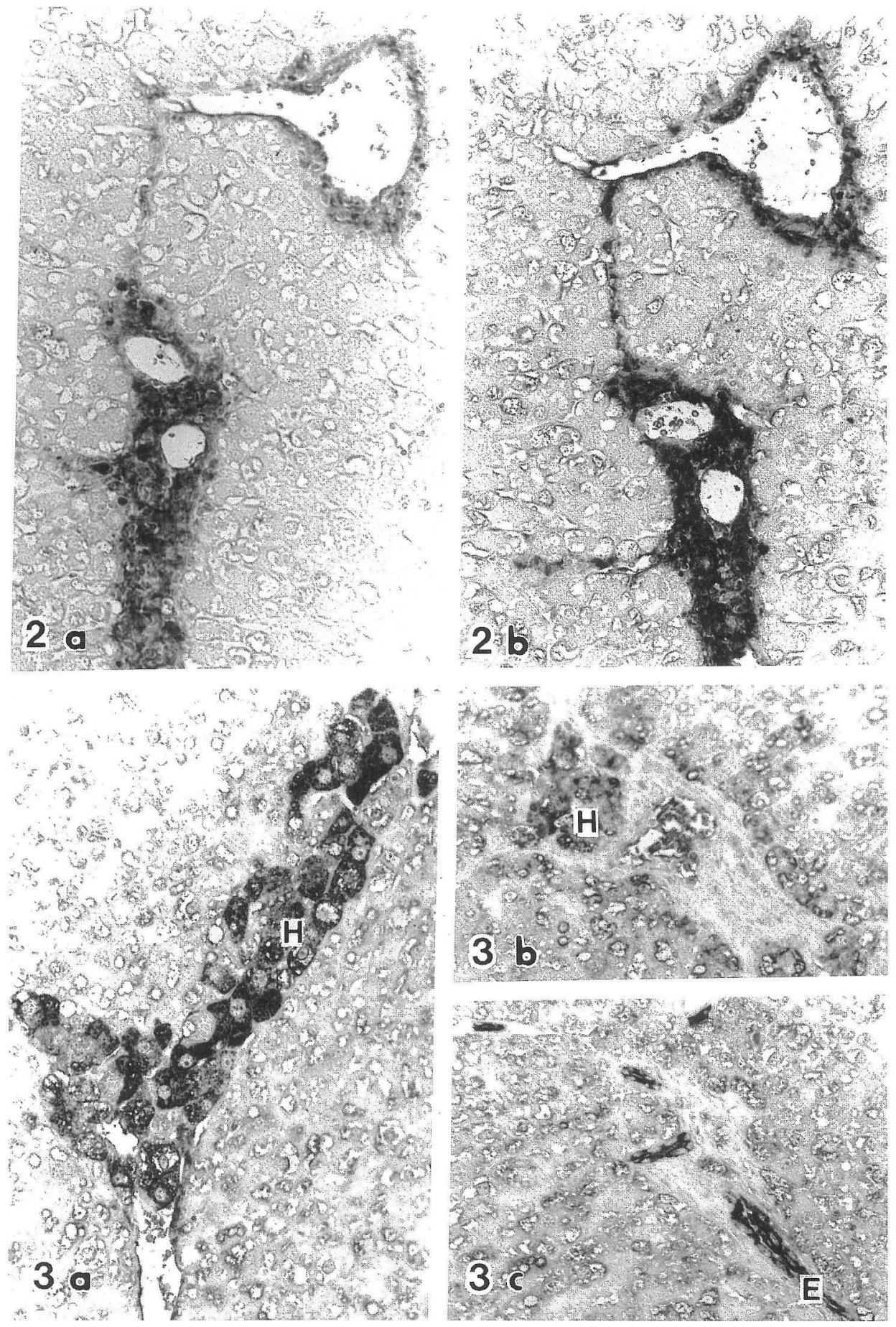

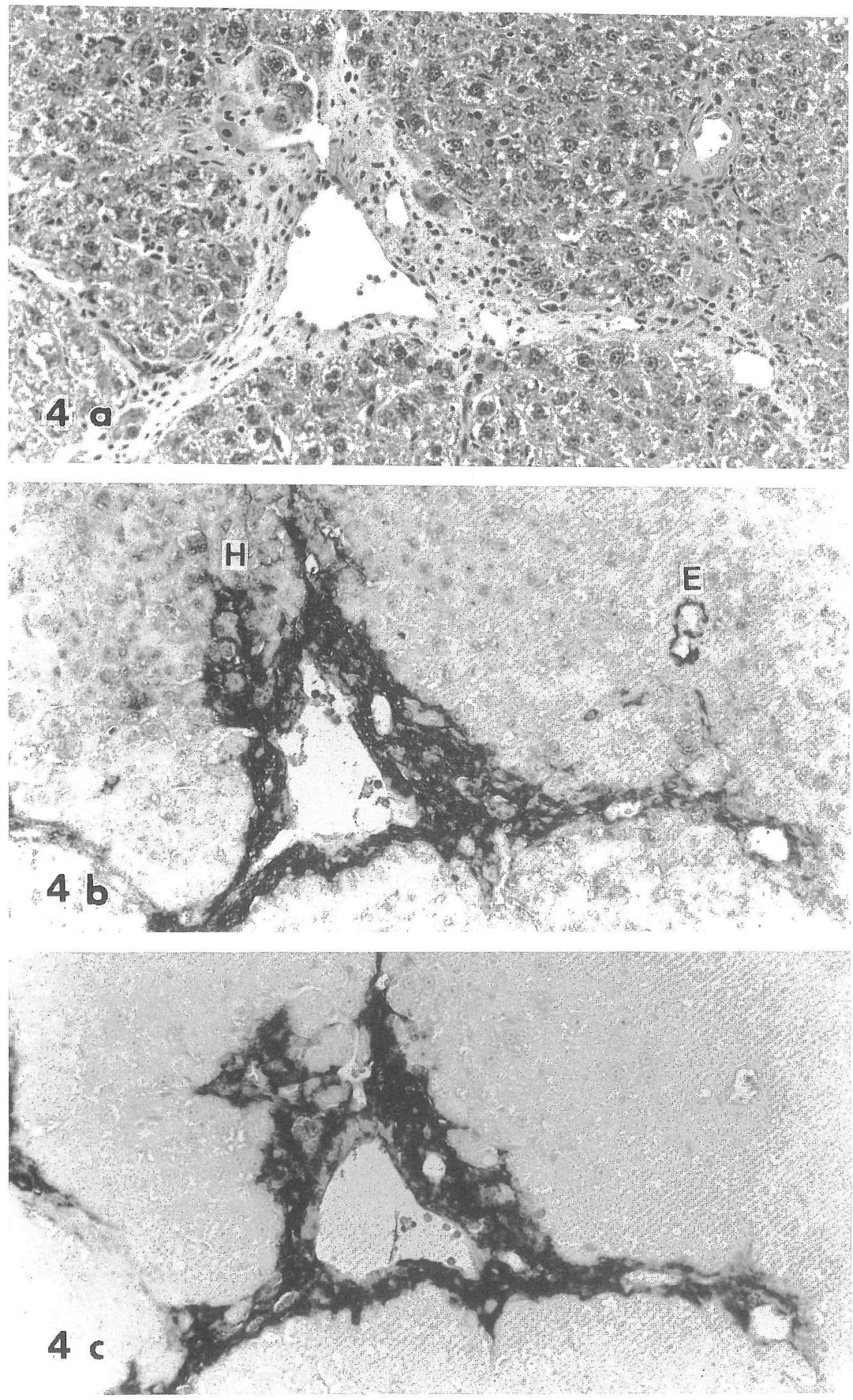


\section{REFERENCES}

1. Aida, T., Kao, C., Ebert, J., Asano, G. and Kao, W.: Synthesis of prolyl 4-hydroxylase by cultured chicken corneal cells. J. Nippon Med. Sch. 56; 361-364, 1989.

2. Clemen, B., Rissel, M. and Peyrol, S.: A procedure for light and electron microscopical intracellular immunolocalization of collagen and fibronectin in rat liver. J. Histochem. Cytochem. 33; 407-414, 1985.

3. Diegelmann, R. F., Guzelian, P. S., Gay, R. and Gay, S.: Collagen formation by the hepatocytes in primary monolayer culture and in vivo. Science 219; 1343-1345, 1982.

4. Friedman, S. L., Roll, F. J., Boyles, J. and Bissello, D. M.: Hepatic lipocytes: The principle collagen producing cells of normal rat liver. Proc. Natl. Acad. Sci. USA. 82; 8681-8686, 1985.

5. Griffin, C. A., Emanuel, B. S., Hansen, J. R., Cavenee, W. K. and Myers, J. G.: Human collagen genes encoding basement membrane $\alpha 1$ (IV) and $\alpha 2$ (IV) chains map to the distal long arm of chromosome 13. Proc. Natl. Acad. Sci. USA. 84; 512-516, 1987.

6. Hata, R., Ninomiya, Y. and Sano, J.: Activation of collagen syntheis in primary culture of rat liver parenchymal cells. J. Cell. Physiol. 122; 333-342, 1985.

7. Hayashi, M., Ninomiya, Y., Parsons, J., Hayashi, K., Olsen, B. R. and Trelstad, R. L.: Differential localization of mRNAs of collagen type I and II in chick fibroblasts, chondrocytes, and corneal cells by in situ hybridization using cDNA probes. J. Cell Biol. 102; 2302-2309, 1986.

8. Henson, P. M. and Johnson, R. B. Jr.: Tissue injury in inflammation oxidants proteases and cationic protein. J. Clin. Invest. 79; 669-674, 1987.

9. Imlay, J. A. and Linn, S.: DNA damage and oxygen radical toxicity. Science 240; 1302-1309, 1988.

10. Kao, W.W-Y., Nakazawa, M. and Aida, T.: Isolation of cDNA and genomic DNAs of $\beta$ subunit of chicken prolyl 4-hydroxylase. Conn. Tiss. Res. 18; 157-174, 1988.

11. Kivirikko, K. I., Cunninghan, L. W. and Frederick, D. W.: Posttranslational enzymes in the biosynthesis of collagen: Intracellular enzyme. Methods in Enzymol. 82; 245-304, 1982.

12. Martinez-Hermandez. A.: The hepatic extracellular matrix II. Electron immunohistochemical study in rats with $\mathrm{CCl}_{4}$-induced cirrhosis. Lab. Invest. 53; 166-186, 1985.

13. Matsumoto, E., Muragaki, Y. and Ooshima, A.: Increased serum type IV collagen peptide in carbon tetrachloride-treated rats. Acta Pathol. Jpn. 39; 23-29, 1989.

14. McGee, J. O. D. and Patrick, R. S.: The role of perisinusoidal cells in hepatic fibrogenesis. Lab. Invest. 26; 429-440, 1972.

15. Milani, S., Herbst, H. Schuppan, D., Hahn, E. G. and Stein, H.: In situ hybridization for procollagen Type I, III and IV mRNA in normal and fibrotic rat liver: Evidence for predominant expression in nonparenchymal liver cells. Hepatology 10; 84-92, 1989.

16. Motomura, H., Ozaki, I. and Sakai, T.: Expression of procollagen mRNA in liver fibrosis and its regulatory mechanisms. Kan Tan Sui 18; 397-406, 1989 (in Japanese).

17. Moriyama, M.: Effect of $\alpha$-tocopherol induced by $\mathrm{CCl}_{4}$ of administration liver. J. Nippon Med. Sch. 39; 146-163, 1972 (in Japanese).

18. Pierce, R. A., Glaug, M. R. and Deak, S. B.: Increased procollagen mRNA levels in carbon tetrachloride-induced liver fibrosis in rats. J. Biol. Chem. 262; 1652-1658, 1987.

19. Roguska, M. A. and Gudas, L. J.: An increase in prolyl 4-hydroxylase activity occurs during the retinoic acid-induced differentiation of mouse teratocarcinoma stem cell lines F9 and P19. J. Biol. Chem. 260; 13893-13896, 1985.

20. Sakakibara, K., Saito, M., Umeda, M., Enaka, K. and Tsukada, Y.: Native collagen formation by liver parenchymal cells in culture. Nature 262; 316-318, 1976.

21. Seyer, J. M.: Interstitial collagen polymorphism in rat liver with $\mathrm{CCl}_{4}$-induced cirrhosis. Biochim. Biophys Acta 629; 490-498, 1980.

22. Taguchi, K. and Asano, G.: Neovascularization of pericellular fibrosis in alcoholic liver disease. Acta Pathol. Jpn. 38; 615-626, 1988. 
23. Timpl, R.: Structure and biological activity of basement membrane proteins. Eur. J. Biochem. 180; 487-502, 1989.

24. Tsutsumi, M., Takada, A., Takase, S. and Ooshima, A.: Connective tissue components in cultured parenchymal and non parenchymal cells of rat liver. Lab. Invest. 58; 88-92, 1988.

25. Wang, S-Y., Larosa, G. J. and Gudas, L. J.: Molecular cloning of gene sequences trascriptionally regulated by retinoic acid and dibutyryl cyclic AMP in cultured mouse teratocarcinoma cells. Dev. Biol. 107; 75-86, 1985.

26. Wood, L., Theriault, N. and Vogeli, G.: cDNA clones completing the nucleotide and derived amino acid sequence of the alpha I chain of basement membrane (type IV) collagen from mouse. FEBS Lett. 227; 5-8, 1988. 